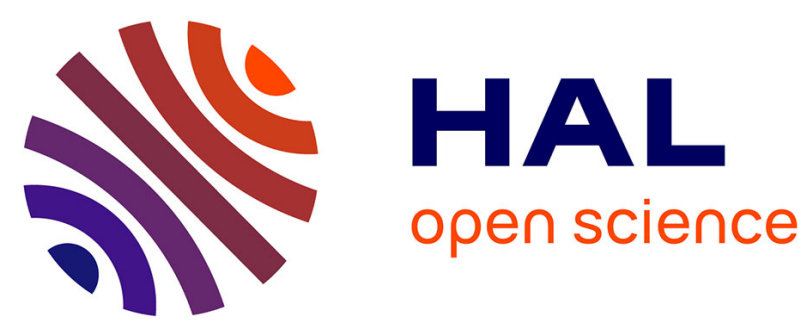

\title{
Assessing Ge-132 as an antioxidant in organic and water-containing media
}

\author{
A.A. Vishtorskaya, E.A. Saverina, V.M. Pechennikov, I.V. Krylova, A.V. \\ Lalov, M.A. Syroeshkin, M.P. Egorov, V.V. Jouikov
}

\section{- To cite this version:}

A.A. Vishtorskaya, E.A. Saverina, V.M. Pechennikov, I.V. Krylova, A.V. Lalov, et al.. Assessing Ge132 as an antioxidant in organic and water-containing media. Journal of Organometallic Chemistry, 2018, 858, pp.8-13. 10.1016/j.jorganchem.2018.01.004 . hal-01713500

HAL Id: hal-01713500 https://hal-univ-rennes1.archives-ouvertes.fr/hal-01713500

Submitted on 25 Apr 2018

HAL is a multi-disciplinary open access archive for the deposit and dissemination of scientific research documents, whether they are published or not. The documents may come from teaching and research institutions in France or abroad, or from public or private research centers.
L'archive ouverte pluridisciplinaire HAL, est destinée au dépôt et à la diffusion de documents scientifiques de niveau recherche, publiés ou non, émanant des établissements d'enseignement et de recherche français ou étrangers, des laboratoires publics ou privés. 


\title{
Assessing Ge-132 as an antioxidant in organic and water-containing media
}

\author{
Antonina A. Vishtorskaya ${ }^{1,2}$, Evgeniya A. Saverina ${ }^{1,2,3}$, Valery M. Pechennikov ${ }^{2}$, \\ Irina V. Krylova ${ }^{1}$, Andrey V. Lalov ${ }^{1}$, Mikhail A. Syroeshkin ${ }^{1}{ }^{*}$, Mikhail P. Egorov $^{1}$, \\ and Viatcheslav V. Jouikov ${ }^{3}$
}
${ }^{1}$ N.D. Zelinsky Institute of Organic Chemistry RAS, Moscow, Russia, syroeshkin@ioc.ac.ru
${ }^{2}$ I.M. Sechenov First Moscow State Medical University, Russia
${ }^{3}$ UMR CNRS 6226 ISCR, Univertsity of Rennes 1, Rennes, France

\begin{abstract}
The antioxidant activity of Ge-132 (2-carboxyethylgermanium sesquioxide, $\left.\left[\left(\mathrm{O}_{0.5}\right)_{3} \mathrm{GeCH}_{2} \mathrm{CH}_{2} \mathrm{COOH}\right]_{n}\right)$, a widely used organic germanium dietary supplement, was assessed by cyclic voltammetry and through its interaction with a stable radical 2,2,-diphenyl-1picrylhydrazyl (DPPH) monitored by UV-Vis and EPR spectroscopy in water, $\mathrm{CH}_{3} \mathrm{CN}$, DMF, $\mathrm{MeOH}$, and their mixtures with water. The results obtained by these methods are coherent in that Ge-132 can manifest its antioxidant activity only in the absence of water because the latter hydrolyses its Ge-O-Ge fragment responsible for quenching free radicals. Thus, contrary to a common use of Ge-132 as a water-soluble agent, it can act as an antioxidant solely in a lipid environment, which is important for understanding the mechanism of its biological activity.
\end{abstract}

Keywords: antioxidants, germanium sesquioxides, Ge-132, cyclic voltammetry, DPPH, UV spectroscopy, EPR, HRMS.

\section{Introduction}

Controlling the level of free radicals involved in aerobic metabolism in living organisms $\left[{ }^{1}\right]$ is important for handling oxidative stress and pathophysiology of several diseases $\left.{ }^{2}\right]$ and supposedly for aging-related issues $\left[{ }^{3}\right]$. Their level is normally regulated by enzymes (superoxide dismutase etc), non-enzymatic antioxidants such as glutathione, vitamins A, C, E [2, $\left.{ }^{4},{ }^{5}\right]$ and exogenous antioxidants $\left.{ }^{6}\right]$ which form two groups, hydrophilic (hydrosoluble) and hydrophobic (liposoluble) $\left[{ }^{1},{ }^{6}, 7\right]$, depending on the media in which they are more efficiently blocking free radicals. Low toxicity of Ge sesquioxides $\left[{ }^{8}\right]$, and particularly the efforts of Asai Germanium Company worked out the advent of 2-carboxyethylgermanium sesquioxide (Ge-132) reported to have - besides immunomodulating $\left[{ }^{9-11}\right]$, anti-inflammatory, anti-virus, hepato and radioprotector activity $\left(\left[^{12}\right]\right.$ and refs therein) - antioxidant properties [ $\left[{ }^{9}, 13-18\right]$. Although this germanium preparation is being intensively studied $\left[{ }^{19-21}\right]$ and even commercialized, its antioxidant mechanism is far from being established. For its understanding, two aspects of chemistry of Ge-132 seem of prime importance: (i) 2D polymer and a monomer triol forms exist in hydrolysis equilibrium (Scheme 1) ${ }^{[16}{ }^{16}$ and (ii) interaction of Ge-132 with free radicals supposedly involves a Ge-O-Ge link $\left[{ }^{22},{ }^{23}\right]$, absent in the monomer (Scheme 2). In the light of this, one can expect the antioxidant activity of Ge-132 to depend strongly on the presence of water in its environment.

To the best of our knowledge, this issue has never been addressed. This aspect is especially intriguing since Ge-132 is primarily known as water-soluble germanium supplement $\left[{ }^{9}, 11\right]$. 


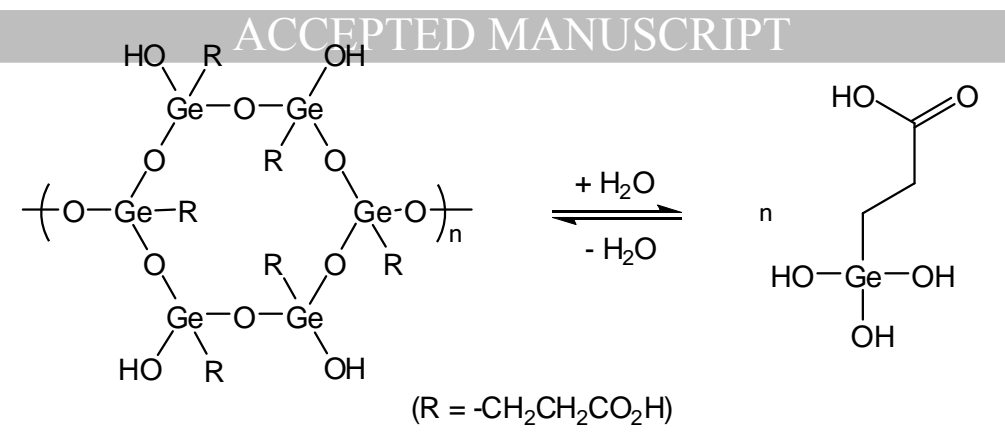

Scheme 1. Solid (polymer) $\left[{ }^{24}\right]$ and water soluble $\left[{ }^{16},{ }^{25}\right]$ forms of Ge-132.

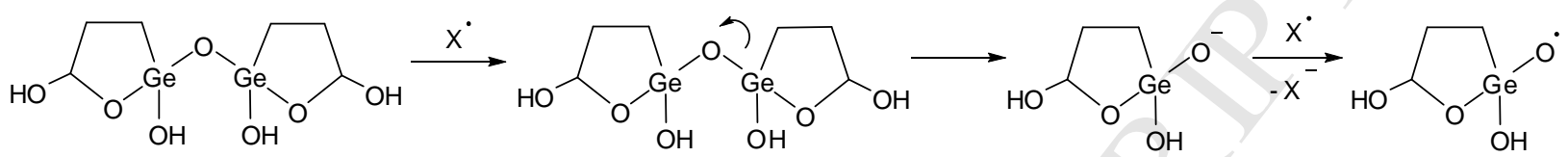

Scheme 2. Proposed mechanism of the antioxidant action of Ge-132 (dimeric form*, adapted from $\left.\left[{ }^{22}, 23\right]\right)$.

The present communication is an attempt to assess the antioxidant activity of Ge-132 in aprotic $\left(\mathrm{CH}_{3} \mathrm{CN}, \mathrm{DMF}\right)$ and protic $(\mathrm{MeOH})$ media, dry and in the presence of water. Cyclic voltammetry $\left.{ }^{26-28}\right]$ of Ge-132 and UV-Vis and EPR spectroscopy for monitoring the decay of 2,2-diphenyl-1-picrylhydrazyl (DPPH) in its reaction with Ge-132 $\left[{ }^{29},{ }^{30}\right]$ were used as standard methods in in vitro antioxidant assays.

\section{Results and Discussion}

\section{Mass-spectrometry}

In a number of previous studies $\left[{ }^{31}\right]$, MS spectra of Ge-132 are essentially obtained from aqueous or $\mathrm{CH}_{3} \mathrm{CN}-\mathrm{H}_{2} \mathrm{O}$ solutions and therefore reflect a complex dynamic equilibrium of its hydrolysis. Albeit $\mathrm{M}, 2 \mathrm{M}-\mathrm{H}_{2} \mathrm{O}, 3 \mathrm{M}-2 \mathrm{H}_{2} \mathrm{O}\left[{ }^{31,32}\right]$ and higher, up to a nonamer $\left[{ }^{33}\right]$, mass clusters were observed in such mixtures (heavier oligomer forms of Ge-132 were reported for solid polymer samples, see e.g. $\left[{ }^{24}\right]$ ), the product distribution in these reports, - depending on the media, temperature and other experimental conditions, - attests that the presence of water promotes the formation of the hydrolyzed triol form of Ge-132 $\left.{ }^{25}\right]$ (for first structurally characterized germane triol see $\left[{ }^{34}\right]$ ), lacking the Ge-O-Ge unit and therefore devoid of the antioxidant properties.

In order to make this point clear, HRMS $\left[{ }^{35}\right]$ spectra of Ge-132 were recorded from its acetonitrile solution using electrospray ionization (ESI) allowing a transfer of the ions in solution into the gas phase. Main peak clusters with characteristic germanium polyisotope pattern (figure 1) confirm the prevalence of oligomer (containing non-hydrolyzed Ge-O-Ge links) forms in $\mathrm{CH}_{3} \mathrm{CN}$. Besides antioxidant-active dimer $(\mathrm{m} / \mathrm{z}=339)$ and trimer $(\mathrm{m} / \mathrm{z}=520)$, some amount of anionic monomer forms $\mathrm{HO}(\mathrm{O}) \mathrm{GeCH}_{2} \mathrm{CH}_{2} \mathrm{COO}^{-}(\mathrm{m} / \mathrm{z}=179)$ and $(\mathrm{HO})_{3} \mathrm{GeCH}_{2} \mathrm{CH}_{2} \mathrm{COO}^{-}(\mathrm{m} / z=$ 197) was also detected in this media, supposedly arising from the hydrolysis of Ge-132 by residual water in $\mathrm{CH}_{3} \mathrm{CN}$.

\footnotetext{
* As suggested by the reviewer of this paper, Lewis drawings involving a $\mathrm{Ge}=\mathrm{O}$ double bond in $\left[{ }^{22,23}\right]$ are obviously incorrect; more appropriate for the dimer and higher oligomer forms appear to be the structures with two $\mathrm{Ge}-\mathrm{O}$ bonds and one $\mathrm{Ge}-\mathrm{OH}$ pending group.
} 

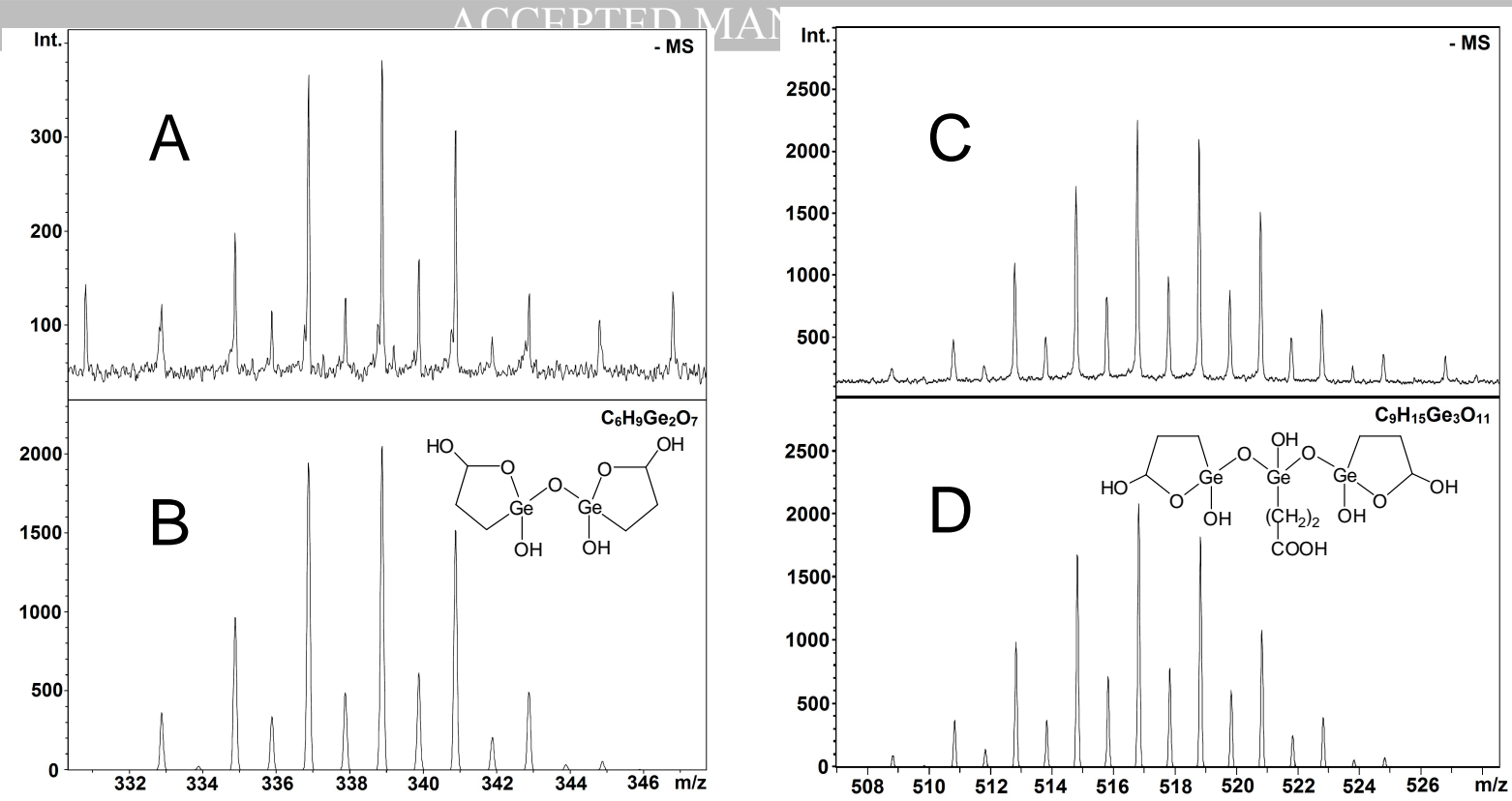

Figure 1. Fragments of the ESI-HRMS negative ion spectrum of Ge-132 in $\mathrm{CH}_{3} \mathrm{CN}$ : (A, C) experimental, $(\mathrm{B}, \mathrm{D})$ calculated for the dimer and trimer species. Ionization at spray needle voltage $3.2 \mathrm{kV}, \mathrm{T}=180^{\circ} \mathrm{C}$.

\section{Cyclic voltammetry}

Though voltammetry is commonly used for assessing the redox activity of antioxidants $\left[{ }^{26-28}\right]$, surprisingly there were no reports on the electrooxidation of Ge-132 so far. The only account on electrochemistry of $\mathrm{Ge}-132$ deals with its reduction at an $\mathrm{Hg}$ electrode in aqueous acid solutions leading to its decomposition to elemental germanium $\left[{ }^{36}\right]$.

In order to check the Ge-132 hydrolysis hypothesis and to reveal the role of water in its antioxidant activity, we studied its electrochemical behavior by cyclic voltammetry at $\mathrm{Pt}$ and glassy carbon $(\mathrm{GC})$ electrodes in aprotic $\left(\mathrm{CH}_{3} \mathrm{CN}\right.$, DMF) and protic $(\mathrm{MeOH})$ solvents and in their mixtures with water. In $\mathrm{CH}_{3} \mathrm{CN} / \mathrm{Bu}_{4} \mathrm{NBF}_{4}$ (Figure 2) and in $\mathrm{DMF} / \mathrm{Bu}_{4} \mathrm{NClO}_{4}, \mathrm{Ge}-132$ shows a distinct oxidation step $\left(E_{\mathrm{p}}{ }^{\mathrm{ox}}=1.15 \mathrm{~V}\right.$ vs SCE$)$ at the potentials comparable to those of phenolic antioxidants $\left[{ }^{37}\right]$. A small pre-peak seen in first scan when using $\mathrm{Bu}_{4} \mathrm{NBF}_{4}$ is related to adsorption at the electrode as it disappears in the following scans or when using the supporting electrolyte with more adsorptive $\mathrm{ClO}_{4}{ }^{-}$anion. Upon addition of small amounts of water, the oxidation peak at $1.15 \mathrm{~V}$ shifts towards more positive potentials, rapidly merging with the media limit, so that when water content in $\mathrm{CH}_{3} \mathrm{CN}$ exceeds $1: 1(\mathrm{v} / \mathrm{v})$, Ge-132 does not show any oxidation signal and hence any antioxidant activity. In $\mathrm{MeOH} / 0.1 \mathrm{M} \mathrm{Bu}_{4} \mathrm{NBF}_{4}$, only an illshaped oxidation peak is observed (Figure 2) disappearing in wet solution. No oxidation was observed in aqueous solutions $\left(\mathrm{H}_{2} \mathrm{O} / 0.1 \mathrm{M} \mathrm{NaNO}_{3}\right)$.

On the side of reduction, in aqueous $0.1 \mathrm{M} \mathrm{LiClO}_{4}$ solution at a $\mathrm{GC}$ electrode, $\mathrm{Ge}-132$ shows a peak at $E_{\mathrm{p}}{ }^{\text {red }}=-1.64 \mathrm{~B}$ vs SCE whose intensity $i_{\mathrm{p}}$ is linear with the substrate concentration (Figure 3). At a Pt electrode, the reduction occurs at $-0.80 \mathrm{~V}$ supposedly corresponding to the reduction of acid $\mathrm{OH}$ protons, facilitated at transition metal cathodes $\left[{ }^{38}\right]$. In aprotic polar solvents $\left(\mathrm{CH}_{3} \mathrm{CN}\right.$, DMF), Ge-132 does not show any reduction signals up to the discharge of the media. However, its reduction can be re-evoked upon progressive addition of water to these solutions (while the oxidation peak disappears, see above), perfectly corroborating the hydrolysis hypothesis.

Interestingly, the reversible reduction of $\mathrm{O}_{2}$ in $\mathrm{CH}_{3} \mathrm{CN} / 0.1 \mathrm{M} \mathrm{Bu}_{4} \mathrm{NBF}_{4}$ loses its reversibility in the presence of Ge-132 (not reducible itself under these conditions) and a prepeak of hydroperoxy form appears on the voltammogram. 


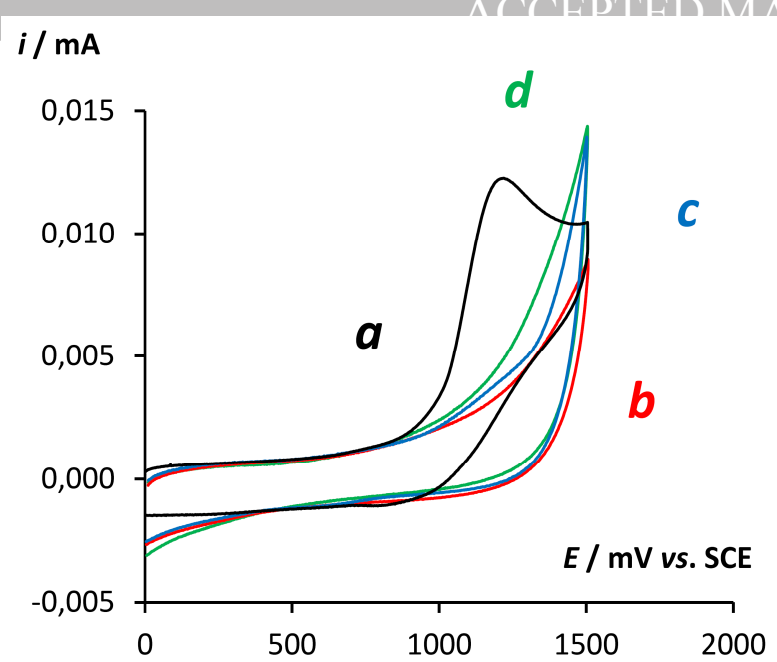

Figure 2. Oxidation of Ge-132 $\left(1 \mathrm{mmol} \mathrm{L}^{-1}\right)$ at a GC disk electrode $(d=1.7 \mathrm{~mm})$ in: (a) $\mathrm{CH}_{3} \mathrm{CN} / 0.1 \quad \mathrm{M} \quad \mathrm{Bu}_{4} \mathrm{NBF}_{4}$, (b) mixture $\mathrm{CH}_{3} \mathrm{CN}-\mathrm{H}_{2} \mathrm{O}(1: 1 \mathrm{v} / \mathrm{v}) / 0.1 \mathrm{M} \mathrm{Bu}_{4} \mathrm{NBF}_{4}$, (c) $\mathrm{MeOH} / 0.1 \mathrm{M} \mathrm{Bu}_{4} \mathrm{NBF}_{4}$ and (d) $\mathrm{H}_{2} \mathrm{O} / 0.1 \mathrm{M}$ $\mathrm{NaNO}_{3}$. Scan rate $v=0.1 \mathrm{~V} \mathrm{~s}^{-1} . \mathrm{T}=298 \mathrm{~K}$. $i, \mathrm{~mA}$

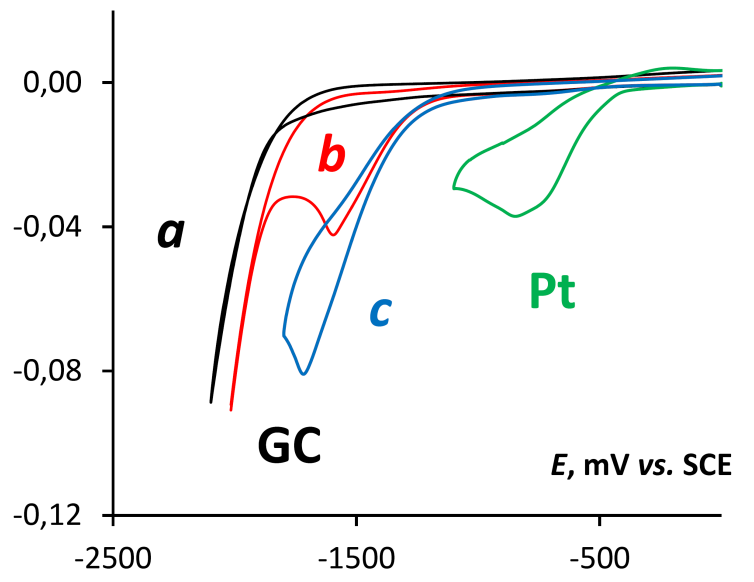

Figure 3. Reduction of Ge-132 (in $\mathrm{H}_{2} \mathrm{O} / 0.1$ $\left.\mathrm{M} \mathrm{LiClO}_{4}\right)$ at a $\mathrm{Pt}\left(4.89 \mathrm{mmol} \mathrm{L}^{-1}\right)$ and a GC electrodes. (a) baseline, (b) and (c) [Ge-132] $=2.44$ and $4.89 \mathrm{mmol} \mathrm{L}^{-1}$, respectively; Scan rate $v=0.1 \mathrm{~V} / \mathrm{s} . \mathrm{T}=298 \mathrm{~K}$.

Thus in the redox context, Ge-132 exhibits the antioxidant efficiency comparable to that of other derivatives of this kind $\left[{ }^{37}\right]$; however this can solely be developed in the absence of water. The presence of the latter in the media rapidly reduces its antioxidant activity until the total loss of it.

\section{UV-Vis spectroscopy}

The antioxidant activity of compounds is often assessed via their ability to scavenge free radicals, e.g. widely used 2,2-diphenyl-1-picrylhydrazyl (DPPH) $\left.{ }^{29,}{ }^{30}\right]$. This stable radical can be used for the assays of both hydrophilic and lipophilic antioxidants $\left[{ }^{39}\right]$ so the DPPH test was performed here with Ge-132. When DPPH is reduced by $\mathrm{H}^{\bullet}$ transfer from Ge-132 to become the corresponding hydrazine, the intensity of absorbance of DPPH due to $\pi-\pi^{*}$ transition $(\lambda=520$ $\mathrm{nm}$ ) diminishes (Figure 4); the extent of this reaction can be quantified by UV spectroscopy through the Beer-Lambert-Bouguer law $\left[{ }^{40}\right]$.
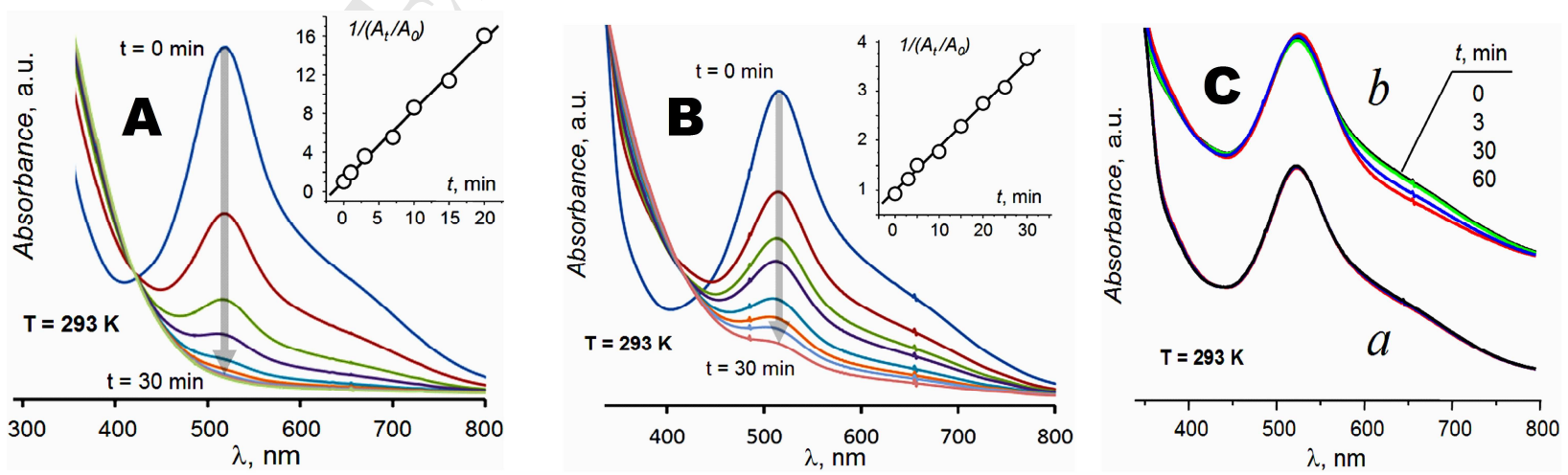

Figure 4. UV spectra of DPPH $\left(0.25 \mathrm{mmol} \mathrm{L}^{-1}\right)$ in $\mathrm{CH}_{3} \mathrm{CN}(\mathrm{A}), \mathrm{MeOH}(\mathrm{B})$ and in $1: 1$ mixtures $\mathrm{CH}_{3} \mathrm{CN} / \mathrm{H}_{2} \mathrm{O}(\mathrm{C}-\mathrm{a})$ and $\mathrm{MeOH} / \mathrm{H}_{2} \mathrm{O}(\mathrm{C}-\mathrm{b})$ in the presence of $\mathrm{Ge}-132\left(0.5 \mathrm{mmol} \mathrm{L}{ }^{-1}\right)$. The insets show the decay of the UV absorbance with time. The spectra in (C) were recorded at $t=0,3,30$ and 60 min of the contact of DPPH with Ge-132. 


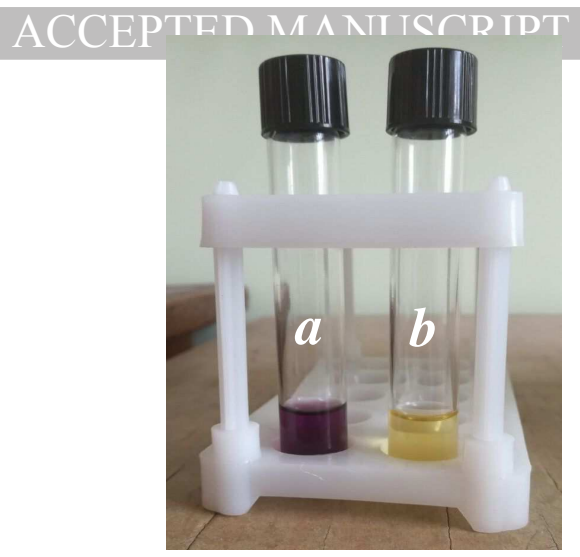

Figure 5. The solutions of DPPH $\left(2.5 \times 10^{-4} \mathrm{M}\right)+\mathrm{Ge}-132\left(5.0 \times 10^{-4} \mathrm{M}\right)$ in (a) $\mathrm{CH}_{3} \mathrm{CN}-\mathrm{H}_{2} \mathrm{O}(1: 1$ $\mathrm{v} / \mathrm{v}$ ) and (b) neat $\mathrm{CH}_{3} \mathrm{CN}$ one hour after mixing the reagents.

In $\mathrm{CH}_{3} \mathrm{CN}$, scavenging of DPPH by Ge-132 is quite efficient (Figure 4): after $3 \mathrm{~min}$, DPPH content is reduced by one order (in $\mathrm{MeOH}$ is takes ca. $15 \mathrm{~min}$ while no visible changes were observed in $\mathrm{CH}_{3} \mathrm{CN}-\mathrm{H}_{2} \mathrm{O}$ ). This simple test is akin to the $\mathrm{EC}_{50}$ evaluation (e.g. $\left[{ }^{22}\right]$ ) receiving criticism $\left[{ }^{41}\right]$, so the kinetics of this reaction was considered (Figure 4). The time evolution of UV-spectra of the solutions of $\left\{\right.$ DPPH $\left.\left(0.25 \mathrm{mmol} \mathrm{L}^{-1}\right)+\mathrm{Ge}-132\left(0.5 \mathrm{mmol} \mathrm{L}^{-1}\right)\right\}$ in $\mathrm{CH}_{3} \mathrm{CN}, \mathrm{MeOH}$, and in their 1:1 mixtures with water is shown in Figure 4. In both aprotic solvents, decay in UV absorbance of DPPH obeys a second-order kinetics, the reaction with Ge132 being more than 7 times faster in $\mathrm{CH}_{3} \mathrm{CN}\left(\mathrm{k}=41.9 \mathrm{~L} \mathrm{~mol}^{-1} \mathrm{~s}^{-1}\right)$ than in $\mathrm{MeOH}(\mathrm{k}=5.8 \mathrm{~L}$ $\left.\mathrm{mol}^{-1} \mathrm{~s}^{-1}\right)$. On the contrary, no reaction was observed between DPPH and $\mathrm{Ge}-132$ in $\mathrm{CH}_{3} \mathrm{CN}-\mathrm{H}_{2} \mathrm{O}$ and $\mathrm{MeOH}-\mathrm{H}_{2} \mathrm{O}(1: 1)$ mixtures even after one hour contact. The invariance of DPPH absorbance in $(\mathrm{C})$ over 1 hour also rules out its possible decrease on light and in protic solvents $\left[{ }^{42}\right]$ that might have affect the measurements in (A) and (B) (Figure 5).

These results are in good agreement with those of cyclic voltammetry: Ge-132 is more efficient antioxidant in $\mathrm{CH}_{3} \mathrm{CN}$ than in $\mathrm{MeOH}$, loosing its antioxidant capacity in the presence of water.

\section{EPR spectroscopy}

Radical scavenging by an antioxidant can be efficiently assessed by EPR spectroscopy, widely used for such studies $\left[{ }^{43}\right]$. We registered EPR spectra of DPPH in the presence of Ge-132 under the conditions similar to those used in UV-Vis study. In $\mathrm{CH}_{3} \mathrm{CN}$ and in its 1:1 mixture with water, DPPH shows a five-line spectrum (Figure 6) with $g=2.0036$ and the ratio of two ${ }^{14} \mathrm{~N}$ constants ca. $0.82\left[{ }^{44}\right]$. When Ge-132 is added to the DPPH solution in dry $\mathrm{CH}_{3} \mathrm{CN}$, this signal completely vanishes after $15 \mathrm{~min}$. In contrast, in $\mathrm{CH}_{3} \mathrm{CN}-\mathrm{H}_{2} \mathrm{O}$ it remains practically unchanged for more than one hour. Second order rate constant of quenching DPPH by Ge-132 in $\mathrm{CH}_{3} \mathrm{CN}$ is close to that from UV-spectroscopy, $\mathrm{k}_{293}=49.5 \mathrm{~L} \mathrm{~mol}^{-1} \mathrm{~s}^{-1}$, indicating that no side reactions interfered with this test.

The data of EPR spectroscopy are thus in a perfect agreement with those from other methods, unequivocally confirming that Ge-132 is an efficient scavenger of free radicals in aprotic media and is totally inactive in the presence of water. 

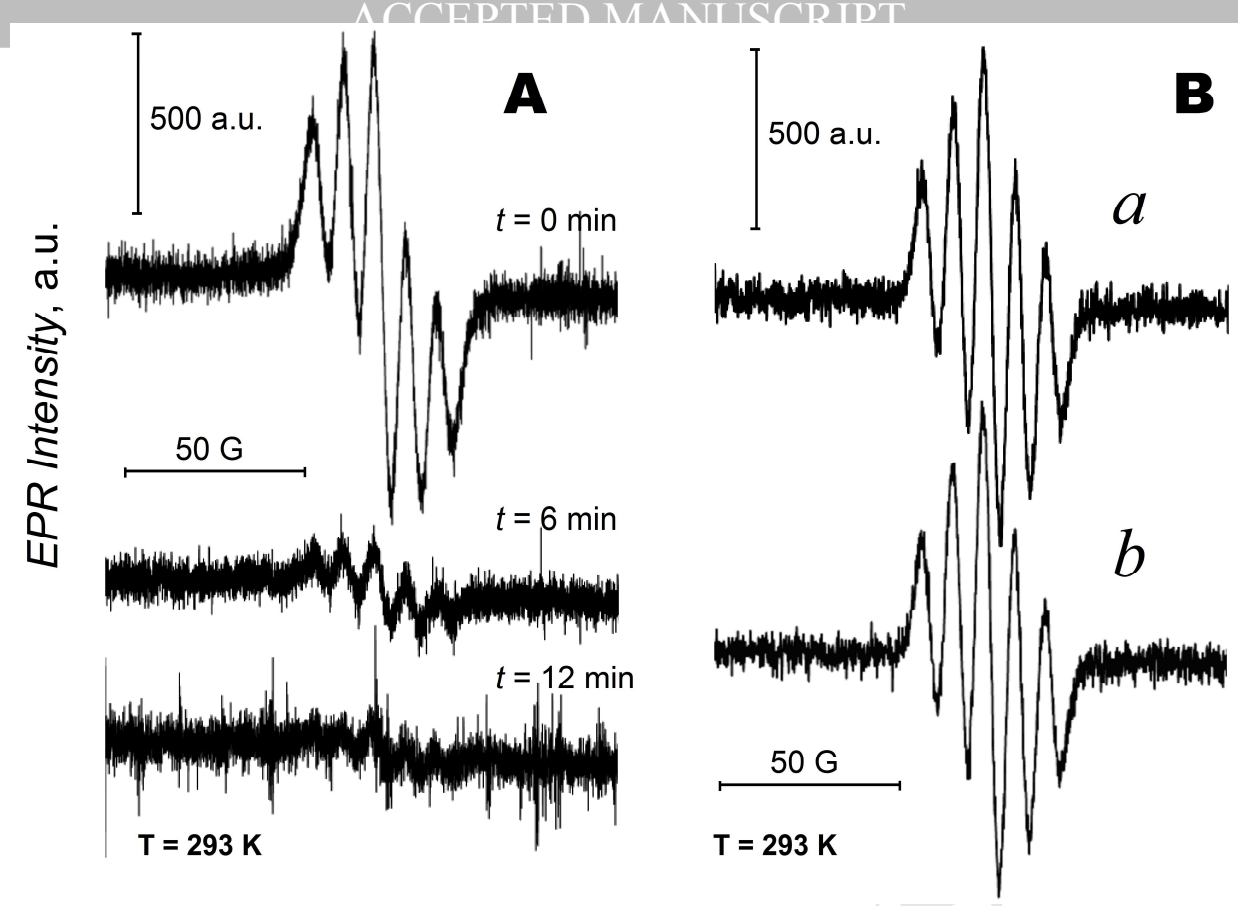

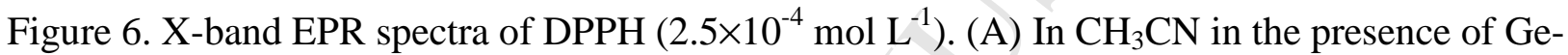
$132\left(5.0 \times 10^{-4} \mathrm{~mol} \mathrm{~L}^{-1}\right)$. (B) In $\mathrm{CH}_{3} \mathrm{CN}-\mathrm{H}_{2} \mathrm{O}(1: 1 \mathrm{v} / \mathrm{v})$ : (a) without $\mathrm{Ge}-132$ and (b) after $60 \mathrm{~min}$ of stay in the presence of Ge-132. Modulation $\mathrm{a}=2 \mathrm{G}$.

\section{Conclusion}

The results of mass spectrometry, cyclic voltammetry, UV and EPR spectroscopy suggest Ge-132 to be an efficient antioxidant only in the absence of water. This finding corroborates the idea that antioxidant capacity of Ge-132, and supposedly of other germanium sesquioxides, is due to the presence of the Ge-O-Ge link $\left[{ }^{22}\right]$ easily hydrolyzable in the presence of water $\left[{ }^{25}\right]$ (Scheme 4). This situation resembles to that in carbon chemistry: while alcohols are stable in air and their oxidation is not a trivial task, the ethers easily react with oxygen to form peroxides. On the other side, the chemistry of germanium sesquioxides and triols is closely related to that of silicon analogs $\left[{ }^{45}\right]$ and is very solvent-dependent in terms of their structural features $\left[{ }^{46}\right]$.

Reversibility of hydrolysis of germanium sesquioxides under close to physiological conditions (neutral $\mathrm{pH}$, ambient temperature) implies that antioxidant capacity of Ge-132 can be substantially enhanced by reducing water content and by increasing its concentration, both factors favoring its active non-hydrolyzed form. This is in line with the fact that though Ge-132 is usually considered as a water soluble germanium preparation $\left[{ }^{9},{ }^{11}\right]$, most of works describing it as an antioxidant concerns its activity in lipid environment, like inhibition of peroxide oxidation of lipids $\left[{ }^{17}\right]$ and lipoproteins $\left[{ }^{15}\right]$, increasing the plasma level of the lipid antioxidant $\alpha$-tocopherol [ ${ }^{9}$ ] etc. In spite of numerous bio-related studies and a common use of Ge-132 as a dietary supplement for humans, the mechanism of antioxidant action of Ge-132 is still poorly defined. Supposedly, Ge-132 may realize it through several ways: as an electron donor, as a metal-chelating agent or a vitamin E protector in metal-catalyzed peroxidations, and by stimulating the activity of radical scavenging enzymes $\left[{ }^{15}\right]$. Our results support the idea that direct reducing action (electron/hydrogen atom donor) of Ge-132, as well as the proposed $\left[{ }^{22},{ }^{23}\right]$ mechanism (Scheme 2), might be efficiently realized under the condition of lack or the absence of water. This fact, along with other in vitro and in vivo studies, will help to unravel the mechanism of biological activity and to better focus the use of this commercialized preparation. 


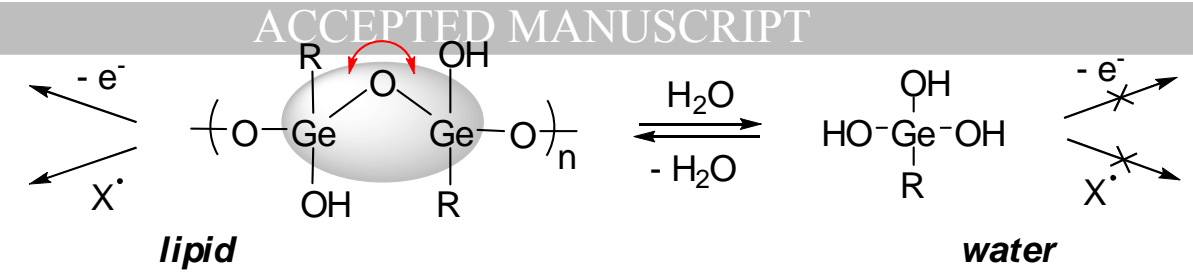

Scheme 4 .

\section{Experimental}

EPR spectra were recorded with a Bruker EMX 6/1 $(9.8 \mathrm{GHz})$ spectrometer, coupled with an ER 4102ST resonator. UV-Vis spectra were registered with Agilent 8453 instrument using a $10 \mathrm{~mm}$ quartz cell. High resolution mass spectra (HR MS) were measured on a Bruker micrOTOF II instrument using electrospray ionization (ESI) at $3200 \mathrm{~V}\left[{ }^{47}\right]$. The measurements were done in a negative ion mode $(3200 \mathrm{~V})$; the mass range from $\mathrm{m} / \mathrm{z} 50$ to $\mathrm{m} / \mathrm{z} 3000$; external or internal calibration was done with ESI Tuning Mix, Agilent. A syringe injection was used for solutions in acetonitrile, methanol, or water (flow rate $3 \mu \mathrm{L} / \mathrm{min}$ ). Nitrogen was applied as a dry gas; interface temperature was set at $180{ }^{\circ} \mathrm{C}$. Cyclic voltammetry was performed using a PCpiloted digital potentiostat IPC-Pro-MF (Econix). A standard thermostated $\left(\mathrm{T}=25 \pm 0.5{ }^{\circ} \mathrm{C}\right) 10$ $\mathrm{ml}$ electrochemical cell was used in a three-electrode configuration. As working electrodes, $\mathrm{Pt}$ $(1.7 \mathrm{~mm})$ and GC $(1 \mathrm{~mm})$ disks were used, polished before each run; a Pt wire was used as an auxiliary electrode. The potentials are referred to the aqueous Saturated Calomel Electrode, (SCE) separated from the analyte by an electrolytic bridge filled with the same solution, and additionally checked using ferrocene standard with $E_{0}\left(\mathrm{Fc}^{+} / \mathrm{Fc}\right)=0.40 \mathrm{~V}$ vs SCE. All measurements were carried out under argon.

HPLC-grade MeCN, DMF, methanol (Aldrich), DPPH, $\mathrm{Bu}_{4} \mathrm{NBF}_{4}, \mathrm{LiClO}_{4}$, and $\mathrm{NaNO}_{3}$ (Fluka) were used as received.

$\mathrm{Ge}-132$ has been prepared from $\mathrm{HGeCl}_{3}$ and ethyl acrylate according to $\left[{ }^{48}\right]$. After drying, the level of the residual humidity in the white powder obtained was ca. 15\%; in the analytical solution, this additional water intake $\left(\leq 7.5 \times 10^{-5} \mathrm{~mol} \mathrm{~L}^{-1}\right)$ is much below its natural residual amount $\left(10^{-4}-10^{-3} \mathrm{~mol} \mathrm{~L}^{-1}\right)$ in dry $\mathrm{CH}_{3} \mathrm{CN}$ or in $\mathrm{MeOH}$.

\section{Acknowledgement}

This work was supported by Grant MK-755.2017.3. High resolution mass spectra were recorded in the Department of Structural Studies of Zelinsky Institute of Organic Chemistry, Moscow.

\section{References}

${ }^{1}$. H. Sies, Experimental Physiology, 1997, 82, 291, doi: 10.1113/expphysiol.1997.sp004024.

. T. Finkel, N.J. Holbrook, Nature, 2000, 408, 239, doi:10.1038/35041687.

${ }^{3}$. H. Nohl, Br. Med. Bull., 1993, 49, 653, doi: 10.1093/oxfordjournals.bmb.a072638.

${ }^{4}$. B.J. Nachtsheim, Science, 2014, 345, 270, doi: 10.1126/science.1257347.

5. S. Vertuani, A. Angusti, S. Manfredini, Curr. Pharm. Des., 2004, 10, 1677, doi: 10.2174/1381612043384655

6 A. M. Pisoschi, A. Pop, Eur. Journ. Medicinal Chem., 2015, 97, 55, doi: 10.1016/j.ejmech.2015.04.040.

${ }^{7}$. E. Niki, Br. J. Cancer, 1987, 55, 153. 
${ }^{8}$. E. Lukevics, L. Ignatovich, Biological activity of organogermanium compounds, Ch. 23, in The Chemistry of Organic Germanium, Tin and Lead Compounds. V. 2, Ed. Z. Rappoport, John Wiley \& Sons, 2002, 1653-1683.

9. T. Nakamura, T. Takeda, Y. Tokuji, Int. J. Vitam. Nutr. Res., 2014, 84, 183, doi: 10.1024/0300-9831/a000205.

10. T. Nakamura, M. Saito, H. Aso, Bioscience, Biotechnology, and Biochemistry, 2012, 76, 375, doi: $10.1271 /$ bbb.110655.

${ }^{11}$. S. Choi, C. Oh, J. Han, J. Park, J.-H. Choi, N.Y. Min, K.-H. Lee, A.J. Park, Y.J. Kim, S.J. Jang, D.-H. Lee, S.W. Ham, European Journal of Medicinal Chemistry, 2010, 45, 1654, doi: 10.1016/j.ejmech.2009.12.069.

12. L.G. Menchikov, M.A. Ignatenko, Pharmaceutical Chemistry Journal, 2013, 46, 635, doi: 10.1007/s11094-013-0860-2.

13. A. Hiraoka, H. Inaba, E. Suzuki, K. Kasai, H. Suzuki, A. Shinohara, M. Shirao, K. Kubo, Y. Yoshimura, Journal of Health Science, 2010, 56, 167, doi: 10.1248/jhs.56.167.

${ }^{14}$. M.K. Yang, Y.G. Kim, Journal of Toxicology and Environmental Health, Part A, 1999, 58, 289, doi: 10.1080/009841099157250.

15. Y. Wakabayashi, Bioscience, Biotechnology, and Biochemistry, 2001, 65, 1893, doi: 10.1271/bbb.65.1893.

16. T. Nakamura, T. Nagura, M. Akiba, K. Sato, Y. Tokuji, M. Ohnishi, K. Osada, Journal of Health Science, 2010, 56, 72, doi: 10.1248/jhs.56.72.

17. J.C. Wang, G.S. Xing, W.D. Hu, T.L. Zhu, Q. Wang, H. Zhao, Chin. Pharm. J., 1994, 29, 23. http://en.cnki.com.cn/Article_en/CJFDTOTAL-ZGYX199401006.htm

18 Y. Mizushima, Y. Shoji, K. Kaneko, Internat. Archives of Allergy and Appl. Immunology, 1980, 63, 338, doi: 10.1159/000232645.

19. T. Nakamura, Y. Shimada, T. Takeda, K. Sato, M. Akiba, H. Fukaya, Future Medicinal Chemistry, 2015, 7, 1233, doi: 10.4155/fmc.15.62.

${ }^{20}$. P. Lu, S. Yao, J. Cai, P. Yang, Bioorganic \& Medicinal Chemistry Letters, 2014, 24, 5294, doi: 10.1016/j.bmcl.2014.09.048.

${ }^{21}$. E. Trikas, G. A. Zachariadis, E. Rosenberg, Analytical and Bioanalytical Chemistry, 2014, 406, 3489, doi: 10.1007/s00216-014-7801-0.

22. S. Yao, J. Jiang, P. Yang, J. Cai Bull. Korean Chem. Soc., 2012, 33, 1121, doi: 10.5012/bkcs.2012.33.4.1121.

23. E. Kim, Y. Jeon, D.Y. Kim, E. Lee, E. Hyun, Theriogenology, 2015, 84, 226, doi: 10.1016/j.theriogenology.2015.03.006.

${ }^{24}$. N. Mizuno, E. Nishibori, M. Oka, T. Jomori, M. Takata, T. Kumasaka, J. Pharm. Sci., 2015, 104, 2482, doi: 10.1002/jps.24486.

${ }^{25}$. H. Yamaguchi, Y. Shimada, T. Takeda, T. Nakamura, N. Mano, Anal. Chem., 2015, 87, 2042, doi: 10.1021/ac504466u.

26. J. Hoyos-Arbelaez, M. Vazquez, J. Contreras-Calderon, Food Chemistry, 2017, 221, 1371, doi: 10.1016/j.foodchem.2016.11.017

${ }^{27}$. J. Sochor, J. Dobes, O. Krystofova, B. Ruttkay-Nedecky, P. Babula, M. Pohanka, T. Jurikova, O. Zitka, V. Adam, B. Klejdus, R. Kizek, Int. J. Electrochem. Sci., 2013, 8, 8464.

${ }^{28}$. A.M. Pisoschi, C. Cimpeanu, G. Predoi, Open Chem., 2015, 13, 824, doi: 10.1515/chem2015-0099.

29. C. Lopez-Alarcon, A. Denicola, Analytica Chimica Acta, 2013, 763, 1, doi: 10.1016/j.aca.2012.11.051.

30. M. Carocho, I.C.F.R. Ferreira, Food Chem. Toxicology, 2013, 51, 15, doi: 10.1016/j.fct.2012.09.021.

${ }^{31}$ J. G. Zhao, Q. Q. Yan, R. Y. Xue, J. Zhang, Y. Q. Zhang, Food Chem., 2014, 161, 22, doi: 10.1016/j.foodchem.2014.03.079. 
32. J. H. Lamb, G. M. A. Sweetman, Rapid Commun. Mass Spectrom., 1996, 10, 594, doi: 10.1002/(SICI)1097-0231(19960331)10:5<594::AID-RCM515>3.0.CO;2-9.

33. J. Wei, J. Chen, J. M. Miller, Rapid Commun. Mass Spectrom., 2001, 15, 169, doi: 10.1002/1097-0231(20010215)15:3<169::AID-RCM207>3.0.CO;2-8.

${ }^{34}$. L.C. Pop, N. Kurokawa, H. Ebata, K. Tomizawa, T. Tajima, M. Ikeda, M. Yoshioka, M.

Biesemans, R. Willem, M. Minoura, M. Saito. Can. J. Chem. 2014, 92, 542, doi: 10.1139/cjc2013-0496.

35. Handbook of modern pharmaceutical analysis, 2nd Edition, Ed. S. Ahuja, Elsevier, 2011, p. 100.

${ }^{36}$ K. Hasebe, S. Hikima, M. Motonari, A. Yamagishi, T. Kakizaki, Electroanalysis, 1994, 6, 779, doi: 10.1002/elan.1140060912.

37. G. Ziyatdinova, A. Khuzina, H. Budnikov, Analytical Letters, 2012, 45, 1670, doi: 10.1080/00032719.2012.677788.

${ }^{38}$. A. V. Bukhtiarov, V. N. Golyshin, O. V. Kuz'min, B. K. Kabanov, A. P. Tomilov, E. A.

Chernyshev, Zhurn. Obshch. Khim. 1986, 56, 1356-1361.

39 . R.L. Prior, X. Wu, K. Schaich, J. Agri. Food Chem., 2005, 53, 4290, doi: 10.1021/jf0502698.

${ }^{40}$. J.K. Kim, J.H. Noh, S. Lee, J.S. Choi, H. Suh, H.Y. Chung, Y.O. Song, W.C. Choi, Bull. Korean Chem. Soc., 2002, 23, 661, doi: 10.5012/bkcs.2002.23.5.661.

41 . M. Foti, J. Agric. Food Chem., 2015, 63, 8765, doi: 10.1021/acs.jafc.5b03839

42 . B. Ozcelik, J.H. Lee, D.B. Min, J. Food Sci., 2003, 68, 487, doi: 10.1111/j.13652621.2003.tb05699.x.

43. I. Spasojevic, Critical Reviews in Clinical Laboratory Sciences, 2011, 48, 114, doi: 10.3109/10408363.2011.591772.

${ }^{44}$. J. Krzystek, A. Sienkiewicz, L. Pardi, L.C. Brunel, Journal of Magnetic Resonance, 1997, 125, 207, doi: 10.1006/jmre.1996.1098.

${ }^{45}$. R. Pietschnig, S. Spirk, Coord. Chem. Rev. 2016, 323, 87, doi: 10.1016/j.ccr.2016.03.010.

${ }^{46}$. S. Spirk, F. Belaj, J. Baumgartner, R. Pietschnig, Z. Anorg. Allg. Chem., 2009, 635, 1048, doi: 10.1002/zaac.200801270.

47. A.M. Tsedilin, A.N. Fakhrutdinov, D.B. Eremin, S.S. Zalesskiy, A.O. Chizhov, N.G. Kolotyrkina, V.P. Ananikov, Mend. Comm., 2015, 25, 454, doi: 10.1016/j.mencom.2015.11.019

${ }^{48}$. N. Kakimoto, M. Akiba, T. Takada, Synthesis, 1985, 272, doi: 10.1055/s-1985-31173. 
The antioxidant activity of Ge-132 was assessed by cyclic voltammetry, UV-Vis and EPR spectroscopy in water, $\mathrm{CH}_{3} \mathrm{CN}, \mathrm{DMF}$ and $\mathrm{MeOH}$

- Ge-132 can manifest its antioxidant activity only in the absence of water because the latter hydrolyses its Ge-O-Ge fragment

- Ge-132 can act as an antioxidant solely in a lipid environment 